Short communication

\title{
Vanadium Complex Derived from N'-(3-Bromo-5-chloro-2-hydroxybenzylidene) -3-methylbenzohydrazide: Synthesis, Crystal Structure and Biological Activity
}

\author{
Zhen-Quan Han, ${ }^{1}$ Shuang Han, ${ }^{2}$ and Yuan Wang ${ }^{3}$ \\ ${ }^{1}$ Applied Technical College, Qiqihar University, Qiqihar 161006, P.R. China \\ ${ }^{2}$ College of Chemistry and Chemical Engineering, Qiqihar University, Qiqihar 161006, P.R. China \\ ${ }^{3}$ Qiqihar Environmental Monitoring Central Station, Qiqihar 161005, P.R. China \\ * Corresponding author: E-mail: hanzhq2088@163.com
}

Received: 20-01-2016

\begin{abstract}
Reaction of $\mathrm{VO}(\mathrm{acac})_{2}$ with $N^{\prime}$-(3-bromo-5-chloro-2-hydroxybenzylidene)-3-methylbenzohydrazide $\left(\mathrm{H}_{2} \mathrm{~L}\right)$ in methanol afforded a new mononuclear vanadium $(\mathrm{V})$ complex, $[\mathrm{VOL}(\mathrm{OMe})(\mathrm{MeOH})]$. Structure of the complex has been characterized by physico-chemical methods and single-crystal X-ray diffraction. The complex crystallizes as the monoclinic space group $P 2_{1} / c$, with unit cell dimensions $a=13.1345(10) \AA, b=18.6279(14) \AA, c=7.8983(8) \AA, \beta=90.248(2)^{\circ}$, $\mathrm{V}=1932.4(3) \AA^{3}, \mathrm{Z}=4, R_{1}=0.0963, w R_{2}=0.2213, S=1.113$. X-ray analysis indicated that the $\mathrm{V}$ atom in the complex is in octahedral coordination. The insulin-like activity of the complex was studied, which can stimulate glucose uptake with 2-DOG uptake value of $0.81 \mathrm{nmol} / 3 \mathrm{~min}$.
\end{abstract}

Keywords: Hydrazone ligand; Vanadium complex; Crystal structure; Insulin-like activity

\section{Introduction}

Transition metal complexes with various ligands have been received much attention because they have interesting biological activities. The increasing interest in the coordination chemistry of vanadium is derived from its well-established chemical and biological functions. ${ }^{1}$ Vanadium is recognized as an essential trace element for different organisms. ${ }^{2}$ The element is present in vanadiumcontaining enzymes such as nitrogenase and haloperoxidases. ${ }^{3}$ Due to structural similarity between vanadates and phosphate and being able to be transported into cells through the anion channel of the plasma membranes, ${ }^{4}$ many vanadium compounds have been shown to increase glucose transport into cells and its oxidation via glycolysis. ${ }^{5}$ Oxovanadium(IV) sulphate has been demonstrated to possess oral insulin-like activity similar to that of the vanadates, with lowered toxicity. ${ }^{6}$ Oxovanadium(IV) salts, however, are known to be poorly absorbed and less bioavailable compared to vanadates. ${ }^{7}$ Therefore, a number of low molecular weight vanadium complexes have been prepared and studied on their insulin-like activity in an attempt to improve the bioavailability of vanadium. ${ }^{8}$ In general, these complexes exhibit insulin-like activity and are effective at lower doses with demonstrable lower toxicities than the vanadium salts. ${ }^{9}$ In addition, such vanadium complexes normalized glucose and lipid values without an increase in insulin levels, and improved glucose tolerance. Considering hydrazone ligands are bioactive species, ${ }^{10}$ and compounds bearing one or more halide atoms on the aromatic rings can improve biological activities, ${ }^{11}$ in the present paper, we report the synthesis, characterization and insulin-like activity of a new vanadium complex, [VOL $(\mathrm{OMe})(\mathrm{MeOH})]$, where $\mathrm{L}$ is the dianionic form of the hydrazone ligand $N^{\prime}$-(3-bromo-5-chloro-2-hydroxybenzylidene)-3-methylbenzohydrazide $\left(\mathrm{H}_{2} \mathrm{~L}\right)$. 


\section{Experimental}

\section{1. General Methods and Materials}

$\mathrm{VO}(\mathrm{acac})_{2}, 3$-bromo-5-chlorosalicylaldehyde and 3methylbenzohydrazide were purchased from Lancaster and used as received. All other reagents were of analytical reagent grade. Elemental analyses of $\mathrm{C}, \mathrm{H}$ and $\mathrm{N}$ were carried out in a 2400 Series-II CHN analyzer. FT-IR spectra were obtained on a Jasco FT/IR-4000 spectrometer with samples prepared as $\mathrm{KBr}$ pellets. Molar conductance was measured with a Shanghai DDS-11A conductometer. In vitro insulin-mimic activity was determined according to the literature method. ${ }^{8}$

\section{2. Synthesis of the Complex}

3-Bromo-5-chlorosalicylaldehyde $(0.23 \mathrm{~g}, 1.0 \mathrm{mmol})$ and 3-methylbenzohydrazide $(0.15 \mathrm{~g}, 1.0 \mathrm{mmol})$ were dissolved and mixed in methanol $(20 \mathrm{~mL})$. The mixture was stirred at room temperature for $10 \mathrm{~min}$ to give a colorless solution. To the solution was added dropwise a methanol solution $(20 \mathrm{~mL})$ containing $\mathrm{VO}(\mathrm{acac})_{2}(0.26 \mathrm{~g}, 1.0 \mathrm{mmol})$. The color changed to brown immediately. The brown mixture was stirred at room temperature for $30 \mathrm{~min}$ and filtered. The filtrate was kept at ambient temperature. Single crystals of the complex, suitable for X-ray diffraction, were grown from the filtrate upon slow evaporation within a few days. The crystals were isolated by filtration, washed with methanol and dried in air. Yield $45 \%$. Characteristic IR data $\left(\mathrm{cm}^{-1}\right): 3445 \mathrm{w}, 1612 \mathrm{~s}, 1497 \mathrm{~s}, 1428 \mathrm{~m}, 1382 \mathrm{~m}, 1355 \mathrm{~m}$, $1283 \mathrm{w}, 1045 \mathrm{~s}, 965 \mathrm{~m}, 927 \mathrm{w}, 898 \mathrm{w}, 820 \mathrm{w}, 712 \mathrm{w}, 641 \mathrm{~m}$, 553w, 470w. Anal. Calcd for $\mathrm{C}_{17} \mathrm{H}_{17} \mathrm{BrClN}_{2} \mathrm{O}_{5} \mathrm{~V}: \mathrm{C} 41.20$, H 3.46, N $5.65 \%$; found: C 41.03, H 3.52, N $5.78 \%$.

\section{3. X-ray Crystallography}

Single-crystal X-ray diffraction data for the complex were collected on a Bruker Smart 1000 CCD diffractometer at 298(2) K with Mo K $\alpha$ radiation $(\lambda=0.71073$ $\AA$ A) by $\Omega$ scan mode. The program SAINT was used for integration of the diffraction profiles. ${ }^{12}$ The structure was solved by direct methods using the SHELXS program of the SHELXTL package and refined by full-matrix leastsquares methods with SHELXL (semi-empirical absorption corrections were applied using the SADABS program). ${ }^{13}$ The positions of the non-hydrogen atoms were located in difference Fourier syntheses and least-squares refinement cycles, and finally refined anisotropically. The methanol hydrogen atom was located from the electronic density map and refined isotropically, with $\mathrm{O}-\mathrm{H}$ distance restrained to $0.85(1) \AA$. The remaining hydrogen atoms of the complex were placed theoretically onto the specific atoms and refined isotropically as riding atoms. Crystallographic data and experimental details for structural analyses are summarized in Table 1 . Selected bond lengths and angles for the complex are listed in Table 2 .
Table 1. Crystallographic information for the complex

\begin{tabular}{|c|c|}
\hline Formula & $\mathrm{C}_{17} \mathrm{H}_{17} \mathrm{BrClN}_{2} \mathrm{O}_{5} \mathrm{~V}$ \\
\hline Formula weight & 495.63 \\
\hline Crystal shape/color & Block/brown \\
\hline Crystal system & Monoclinic \\
\hline Space group & $P 2_{1} / c$ \\
\hline$a(\AA)$ & $13.1345(10)$ \\
\hline$b(\AA)$ & $18.6279(14)$ \\
\hline$c(\AA)$ & $7.8983(8)$ \\
\hline$\beta\left(^{\circ}\right)$ & $90.248(2)$ \\
\hline$V\left(\AA^{3}\right)$ & $1932.4(3)$ \\
\hline$Z$ & 4 \\
\hline$D_{\text {calc }}\left(\mathrm{g} \mathrm{cm}^{-3}\right)$ & 1.704 \\
\hline$\mu(\mathrm{Mo} \mathrm{K} \alpha)\left(\mathrm{mm}^{-1}\right)$ & 2.750 \\
\hline$F(000)$ & 992 \\
\hline Measured reflections & 6361 \\
\hline Unique reflections & 3084 \\
\hline Observed reflections $(I \geq 2 \sigma(I))$ & 2289 \\
\hline Parameters & 250 \\
\hline Goodness of fit on $F^{2}$ & 1.113 \\
\hline$R_{1}, w R_{2}[I \geq 2 \sigma(I)]^{a}$ & $0.0844,0.1851$ \\
\hline$R_{1}, w R_{2}(\text { all data })^{a}$ & $0.1130,0.2095$ \\
\hline Largest different peak and hole $\left(\mathrm{e} \AA^{-3}\right)$ & $0.817,-0.645$ \\
\hline
\end{tabular}

${ }^{a} R_{1}=F_{o}-F_{c} / F_{o}, w R_{2}=\left[\sum w\left(F_{o}^{2}-F c^{2}\right) / \sum w\left(F_{o}^{2}\right)^{2}\right]^{1 / 2}$

Table 2. Selected bond lengths $(\AA)$ and angles $\left(^{\circ}\right)$ for the complex with estimated standard deviations (e.s.d.s) in parentheses

\begin{tabular}{llll}
\hline Bond distances $(\stackrel{\AA}{ })$ & & & \\
\hline V1-O1 & $1.880(6)$ & V1-O2 & $1.958(6)$ \\
V1-O3 & $1.576(8)$ & V1-O4 & $1.757(6)$ \\
V1-O5 & $2.332(8)$ & V1-N1 & $2.134(7)$ \\
\hline Bond angles $\left(^{\circ}\right)$ & & & \\
\hline O3-V1-O4 & $103.2(3)$ & O3-V1-O1 & $98.4(3)$ \\
O4-V1-O1 & $100.3(3)$ & O3-V1-O2 & $98.3(3)$ \\
O4-V1-O2 & $96.5(3)$ & O1-V1-O2 & $153.0(3)$ \\
O3-V1-N1 & $94.6(3)$ & O4-V1-N1 & $160.9(3)$ \\
O1-V1-N1 & $83.6(3)$ & O2-V1-N1 & $74.0(2)$ \\
O3-V1-O5 & $174.8(3)$ & O4-V1-O5 & $81.6(3)$ \\
O1-V1-O5 & $82.6(3)$ & O2-V1-O5 & $79.0(3)$ \\
N1-V1-O5 & $80.4(3)$ & & \\
\hline
\end{tabular}

\section{Results and Discussion}

\section{1. Synthesis and Characterization}

The hydrazone ligand was prepared by reaction of 3-bromo-5-chlorosalicylaldehyde and 3-methylbenzohydrazide in methanol. The ligand was not isolated and purified, and was immediately used to prepare the vanadium complex with $\mathrm{VO}(\mathrm{acac})_{2}$. It should be pointed out that the vanadium in the starting materials is in $\mathrm{V}$ (IV) oxidation state, but it appears to be $\mathrm{V}(\mathrm{V})$ in the product, indicating that it was oxidized by air during the reaction procedures. Elemental analysis of the complex is in accordance with 
the molecular structure proposed by the $\mathrm{X}$-ray analysis. The complex show typical $\mathrm{C}=\mathrm{N}$ absorption at $1612 \mathrm{~cm}^{-1}$, and typical $\mathrm{V}=\mathrm{O}$ absorption at $965 \mathrm{~cm}^{-1}$. ${ }^{14}$ The bands due to $v(\mathrm{~V}-\mathrm{N})$ and $v(\mathrm{~V}-\mathrm{O})$ observed occurred at $470-560$ $\mathrm{cm}^{-1}$. The complex is stable in air at room temperature, and did not decompose when heated up to $250{ }^{\circ} \mathrm{C}$. The molar conductivity of the complex measured in acetonitrile at a concentration of $10^{-3} \mathrm{M}$ is $22 \Omega^{-1} \mathrm{~cm}^{2} \mathrm{~mol}^{-1}$, indicating its non-electrolytic nature in solution. ${ }^{15}$

\section{2. Structure Description of the Complex}

The molecular structure of the complex is shown in Figure 1 . The $\mathrm{V}$ atom is in an octahedral coordination, and is

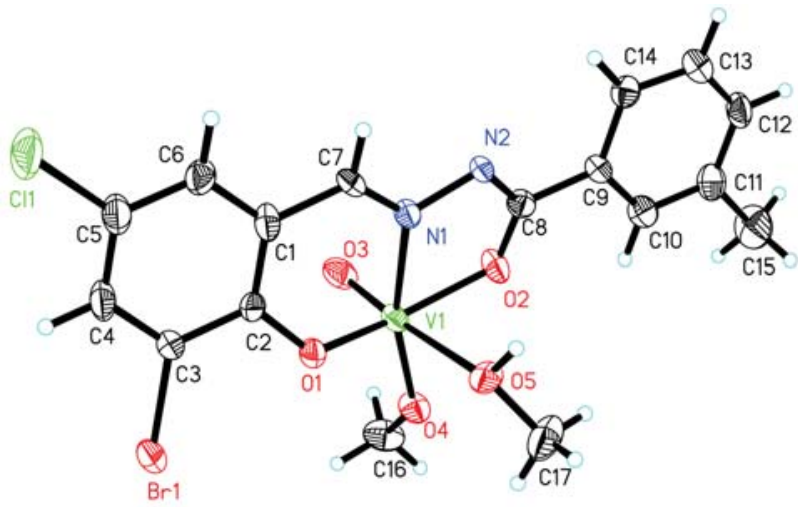

Figure 1. A perspective view of the molecular structure of the complex. Thermal ellipsoids are drawn at the $30 \%$ probability level.

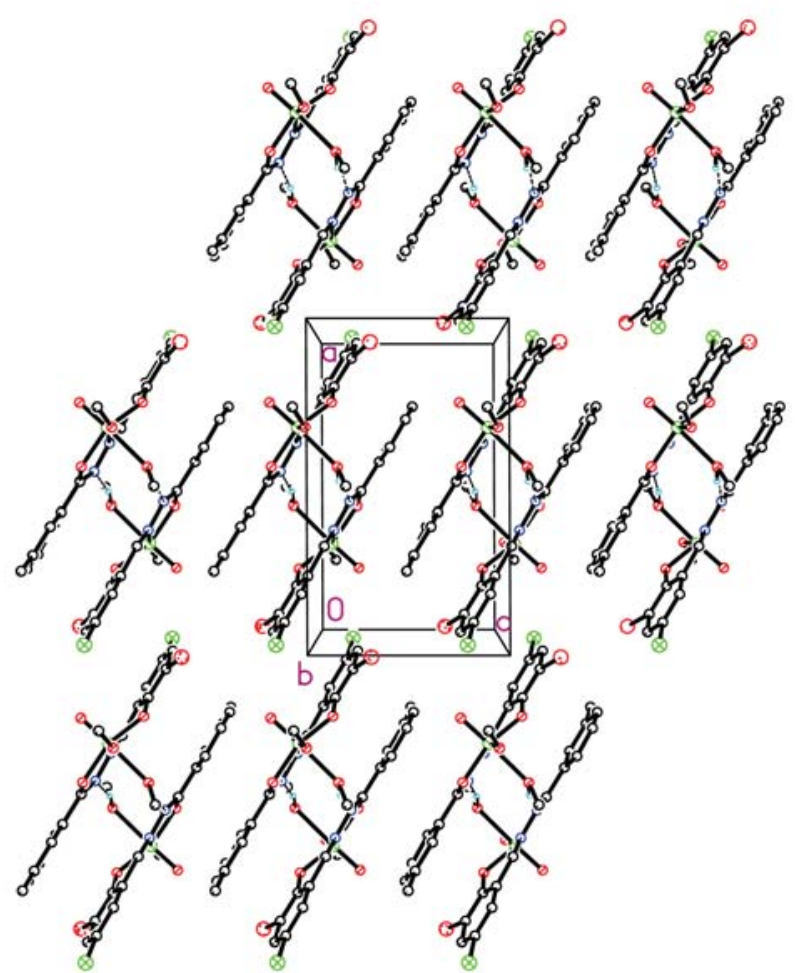

Figure 2. A perspective view of the dimeric structure of the complex. coordinated by one hydrazone ligand, one oxo oxygen atom, one deprotonated methanol molecule and one neutral methanol molecule. The hydrazone ligand coordinates to the $\mathrm{V}$ atom via the phenolate oxygen, imino nitrogen, and enalate oxygen. As expected, the neutral methanol ligand is situated at the opposite position of the oxo oxygen. Thus, the bond of $\mathrm{V} 1-\mathrm{O} 5$ is much longer than that of $\mathrm{V} 1-\mathrm{O} 3$. The $\mathrm{V}$ atom is situated 0.298(2) ̊ from the least-squares plane defined by the equatorial donor atoms, O1, N1, O2 and O4. The distances related to the remaining V-O [1.757(6)-1.959(6) $\mathrm{A}]$ and $\mathrm{V}-\mathrm{N}[2.134(7) \AA]$ bonds are comparable to those observed in similar vanadium $(\mathrm{V})$ complexes. $^{16}$

In the crystal packing (Figure 2), two adjacent molecules are linked via $\mathrm{O} 5-\mathrm{H} 5 \cdots \mathrm{N} 2$ hydrogen bond $\left[\mathrm{O} 5-\mathrm{H} 5=0.85(1) \AA, \mathrm{H} 5 \cdots \mathrm{N} 2^{\mathrm{i}}=2.02(4) \AA, \mathrm{O} 5 \cdots \mathrm{N} 2^{\mathrm{i}}=\right.$ $2.836(9) \AA$, O5-H5 $\cdots \mathrm{N} 22^{\mathrm{i}}=161(12)^{\circ}$; symmetry code for i: $1-x,-y, 1-z]$.

\section{3. Insulin-like Activity}

The presence of the complex in the incubation medium stimulated glucose uptake, with 2-DOG uptake value of $0.81 \mathrm{nmol} / 3 \mathrm{~min}$. However, both insulin (IN) and $\left[\mathrm{VO}(\mathrm{acac})_{2}\right]$ are more effective than the present complex in enhancing glucose uptake by adipocytes, with 2-DOG uptake values of 1.70 and $1.51 \mathrm{nmol} / 3 \mathrm{~min}$, respectively. Further study indicated that the complex inhibited glycerol release by adipocytes in a similar way as that observed with insulin. The results in the present work are similar to that of the vanadium complexes with thiosemicarbazone ligands reported by Beraldo and coworkers. ${ }^{8 \mathrm{c}}$

\section{Supplementary Material}

CCDC-1435661 contain the supplementary crystallographic data for this paper. These data can be obtained free of charge at http://www.ccdc.cam.ac.uk/const/retrieving.html or from the Cambridge Crystallographic Data Centre (CCDC), 12 Union Road, Cambridge CB2 1EZ, UK; fax: +44(0)1223-336033 or e-mail: deposit @ ccdc.cam.ac. uk.

\section{Acknowledgments}

This work was financially supported by the Program for Young Teachers Scientific Research in Qiqihar University (2012k-M05), and the Education Office of Heilongjiang Province (Project No. 12531757).

\section{References}

1. (a) T. Scior, J. A. Guevara-Garcia, F. J. Melendez, H. H. Abdallah, Q. T. Do, P. Bernad, Drug Des. Dev. Ther. 2010, 4, 231-242; 
(b) J. Rivadeneira, D. A. Barrio, G. Arrambide, D. Gambino, L. Bruzzone, S. B. Etcheverry, J. Inorg. Biochem. 2009, 103, 633-642; http://dx.doi.org/10.1016/j.jinorgbio.2008.11.009

(c) L. R. Guilherme, A. C. Massabni, A. Cuin, L. A. A. Oliveira, E. E. Castellano, T. A. Heinrich, C. M. Costa-Neto, J. Coord. Chem. 2009, 62, 1561-1571;

http://dx.doi.org/10.1080/00958970802663555

(d) P. Frank, E. J. Carlson, R. M. K. Carlson, B. Hedman, K. O. Hodgson, J. Inorg. Biochem. 2008, 102, 809-823; http://dx.doi.org/10.1016/j.jinorgbio.2007.12.001

(e) U. Ashiq, R. Ara, M. Mahroof-Tahir, Z. T. Maqsood, K. M. Khan, S. N. Khan, H. Siddiqui, M. I. Choudhary, Chem. Biodivers. 2008, 5, 82-92.

http://dx.doi.org/10.1002/cbdv.200890016

2. M. Mochizuki, E. Kudo, M. Kikuchi, T. Takano, Y. Taniuchi, T. Kitamura, R. Hondo, F. Ueda, Biol. Trace Elem. Res. 2011, 142, 117-126. http://dx.doi.org/10.1007/s12011-010-8741-y

3. Y. L. Hu, C. C. Lee, M. W. Ribbe, Dalton Trans. 2012, 41, 1118-1127. http://dx.doi.org/10.1039/C1DT11535A

4. (a) D. C. Crans, S. Schoeberl, E. Gaidamauskas, B. Baruah, D. A. Roess, J. Biol. Inorg. Chem. 2011, 16, 961-972; http://dx.doi.org/10.1007/s00775-011-0796-5

(b) S. H. Li, J. H. McNeill, Mol. Cell Biochem. 2001, 217, 121-129. http://dx.doi.org/10.1023/A:1007224828753

5. (a) S.-L. Hwang, H. W. Chang, Mol. Cell Biochem. 2012, 360, 401-409; http://dx.doi.org/10.1007/s11010-011-1062-4 (b) D. Sanna, G. Micera, E. Garribba, Inorg. Chem. 2010, 49, 174-187. http://dx.doi.org/10.1021/ic9017213

6. T. C. Delgado, A. I. Tomaz, I. Correia, J. C. Pessoa, J. G. Jones, C. F. G. C. Geraldes, M. M. C. A. Castro, J. Inorg. Biochem. 2005, 99, 2328-2339.

http://dx.doi.org/10.1016/j.jinorgbio.2005.08.014

7. (a) B. Lu, D. Ennis, R. Lai, E. Bogdanovic, R. Nikolov, L. Salamon, C. Fantus, H. Le-Tien, I. G. Fantus, J. Biol. Chem. 2001, 276, 35589-35598;

http://dx.doi.org/10.1074/jbc.M106783200

(b) M. T. Cocco, V. Onnis, G. Ponticelli, B. Meier, D. Rehder, E. Garribba, G. Micera, J. Inorg. Biochem. 2007, 101, 19-29. http://dx.doi.org/10.1016/j.jinorgbio.2006.07.015

8. (a) S. L. Pillai, S. P. Subramanian, M. Kandaswamy, Eur. J. Med. Chem. 2013, 63, 109-117;

http://dx.doi.org/10.1016/j.ejmech.2013.02.002

(b) D. C. Crans, A. M. Trujillo, P. S. Pharazyn, M. D. Cohen, Coord. Chem. Rev. 2011, 255, 2178-2192; http://dx.doi.org/10.1016/j.ccr.2011.01.032

(c) I. C. Mendes, L. M. Botion, A. V. M. Ferreira, E. E. Castellano, H. Beraldo, Inorg. Chim. Acta 2009, 362, 414-420. http://dx.doi.org/10.1016/j.ica.2008.04.029

9. A. A. Nejo, G. A. Kolawole, A. R. Opoku, J. Wolowska, P. Obrien, Inorg. Chim. Acta 2009, 362, 3993-4001. http://dx.doi.org/10.1016/j.ica.2009.05.039

10. M. D. Altintop, A. Ozdemir, G. Turan-Zitouni, S. Ilgin, O. Atlik, G. Iscan, Z. A. Kaplancikli, Eur. J. Med. Chem. 2012, 58, 299-307.

http://dx.doi.org/10.1016/j.ejmech.2012.10.011

11. (a) L. C. Felton, J. H. Brewer, Science 1947, 105, 409-410; http://dx.doi.org/10.1126/science.105.2729.409

(b) M. Gopalakrishnan, J. Thanusu, V. Kanagarajan, R. Govindaraju, J. Enzym. Inhib. Med. Chem. 2009, 24, 52-58; (c) M. Zhang, D.-M. Xian, H.-H. Li, J.-C. Zhang, Z.-L. You, Aust. J. Chem. 2012, 65, 343-350.

http://dx.doi.org/10.1080/14756360801906632

12. Bruker AXS, SAINT software reference manual, Madison, WI, 1998.

13. (a) G. M. Sheldrick, SADABS, Siemens area detector absorption corrected software, University of Göttingen, Germany, 1996;

(b) G. M. Sheldrick, Acta Crystallogr. 2008, A64, 112-122. http://dx.doi.org/10.1107/S0108767307043930

14. A. Sarkar, S. Pal, Polyhedron 2006, 25, 1689-1694. http://dx.doi.org/10.1016/j.poly.2005.11.009

15. W. J. Geary, Coord. Chem. Rev. 1971, 7, 81-122. http://dx.doi.org/10.1016/S0010-8545(00)80009-0

16. (a) Z.-L. You, D.-H. Shi, J.-C. Zhang, Y.-P. Ma, C. Wang, K. Li, Inorg. Chim. Acta 2012, 384, 54-61; http://dx.doi.org/10.1016/j.ica.2011.11.039 (b) Y. Huo, Y.-T. Ye, X.-S. Cheng, Z.-L. You, Inorg. Chem. Commun. 2014, 45, 131-134; http://dx.doi.org/10.1016/j.inoche.2014.04.008 (c) M. He, Q.-Z. Jiao, X.-F. Chen, J. Li, J. Chen, G.-H. Sheng, Z.-L. You, Chinese J. Inorg. Chem. 2015, 31, 1590- 1596;

(d) D. Qu, F. Niu, X. Zhao, K.-X. Yan, Y.-T. Ye, J. Wang, M. Zhang, Z. You, Bioorg. Med. Chem. 2015, 23, 1944-1949; http://dx.doi.org/10.1016/j.bmc.2015.03.036

(e) X. Zhao, X. Chen, J. Li, J. Chen, G. Sheng, F. Niu, D. Qu, Y. Huo, H. Zhu, Z. You, Polyhedron 2015, 97, 268-272; (f) S.-S. Qian, X. Zhao, J. Wang, Z. You, Acta Chim. Slov. 2015, 62, 828-833. http://dx.doi.org/10.1016/j.poly.2015.07.012

\section{Povzetek}

Pri reakciji $\mathrm{VO}(\mathrm{acac})_{2}$ z N'-(3-bromo-5-kloro-2-hidroksibenziliden)-3-metilbenzohidrazida $\left(\mathrm{H}_{2} \mathrm{~L}\right)$ v metanolu smo izolirali nov enojederni vanadijev(V) kompleks, [VOL(OMe)(MeOH)]. Struktura kompleksa je bila določena z fizikalnokemijskimi metodami in monokristalno rentgensko difrakcijo. Spojina kristalizira $\mathrm{v}$ monoklinski prostorski skupini $P 2_{1} / c$ z dimenzijami osnovne celice $a=13.1345(10) \AA, b=18.6279(14) \AA, c=7.8983(8) \AA, \beta=90.248(2) \mathrm{o}, \mathrm{V}=$ 1932.4(3) $\AA^{3}, Z=4, R_{1}=0.0963, w R_{2}=0.2213, S=1.113$. Rentgenska strukturna analiza je razkrila, da ima vanadijev atom oktaedrično koordinacijo. Inzulinu sorodna aktivnost spojine je bila določena, in sicer stimulira vnos glukoze z vrednostmi $2-D O G$ vnosa $0,81 \mathrm{nmol} / 3 \mathrm{~min}$. 